\title{
Effect of a Polyene Antibiotic on Growth and Phosphate Uptake by Candida albicans
}

\author{
By ISRAELA BERDICEVSKY \\ Department of Microbiology, Technion - The KHOUSHY School of Medicine, \\ Haifa, Israel \\ AND NATHAN GROSSOWICZ \\ Department of Bacteriology, The Hebrew University-Hadassah Medical School, \\ Jerusalem, Israel
}

(Received 24 March 1977)

The polyene antibiotic, amphotericin, inhibited phosphate uptake in Candida albicans more strongly than it inhibited growth. Cultures grown from an inoculum of young $(2 \mathrm{~h})$ cells were more affected than those inoculated with old $(24 \mathrm{~h})$ cells. Thus, the polyene displays a double effect on $C$. albicans (and presumably on other eukaryotic cells): it interferes with membrane sterols and also inhibits synthesis of a factor (or factors) during growth. Whether this factor(s) interferes with the uptake of the polyene antibiotic or neutralizes its effect by reacting with it remains unsolved.

\section{INTRODUCTION}

Studies on the mode of action of polyene antibiotics revealed the importance of sterols as the membrane target site of these antifungal agents in yeasts and other eukaryotic organisms (Cirillo, Harsch \& Lampen, 1964; Lampen, 1966; Hamilton-Miller, 1974; Kerridge \& Russell, 1975). This interaction alters the permeability of the membrane of antibioticsensitive cells, causing leakage of cellular constituents and ultimately cell death (Marini, Arnow \& Lampen, 1961 ; Kinsky, 1963; Stachiewicz \& Quastel, 1963). Further studies disclosed that in certain yeast strains calcium ions were closely linked with the sterol site and therefore pretreatment of cells with $\mathrm{Ca}^{2+}$ counteracts the antifungal effect of various polyenes, presumably by barring the latter from reaching the sterol site (Berdicevsky \& Grossowicz, 1972).

Recently, Gale et al. (1975) focused attention on factors other than sterols that influence the sensitivity of cells of Candida albicans towards amphotericin B methyl ester; these include cell wall lipids which apparently act as acceptors binding the drug with intermediate or low specificity. According to Gale and coworkers an increase in the neutral lipid fraction of the cell wall increases the non-specific binding of the polyene antibiotic and decreases the sensitivity of the organism as a whole. Their hypothesis is supported by the finding that sphaeroplasts are more sensitive to polyene than are intact cells of $C$. albicans (Gale et al., 1975).

The experiments reported below confirm the differences in sensitivity towards amphotericin B between exponential phase and stationary phase cells of $C$. albicans, with respect to growth and especially to phosphate uptake, known to be strikingly inhibited by polyenes (Henis \& Grossowicz, 1960). 


\section{METHODS}

Organism and growth. Candida albicans strain 26, from the collection of the Department of Microbiology of the Technion-Medical School, Haifa, Israel, was grown in defined medium of the following composition (g per $100 \mathrm{ml}$ distilled water): glucose, $\mathrm{I} ;\left(\mathrm{NH}_{4}\right)_{2} \mathrm{SO}_{4}, 0.2 ; \mathrm{K}_{2} \mathrm{HPO}_{4}, 0.1$; and $\mathrm{MgSO}_{4} \cdot 7 \mathrm{H}_{2} \mathrm{O}, 0.5 ;$ the $\mathrm{pH}$ was adjusted to $7 \cdot 0$. After autoclaving ( $15 \mathrm{~min}$ at $121^{\circ} \mathrm{C}$ ), the following vitamins, sterilized by filtration, were added aseptically to the medium $\left(\mu \mathrm{g} \mathrm{ml}^{-1}\right.$, final concentration): thiamin hydrochloride, $0.5 ;$ riboflavin, 0.5 ; calcium pantothenate, 0.5 ; niacin, 0.5 ; pyridoxal phosphate, 0.1 ; $p$-aminobenzoic acid, 0.1 ; myo-inositol, 0.1 ; folic acid, 0.01 ; and biotin, 0.04 .

The yeast was also grown in yeast extract medium which contained ( $\mathrm{g}$ per $100 \mathrm{ml}$ distilled water): glucose, 2; Bacto-Peptone (Difco), 0.5; and yeast extract (Difco), 0.5; the pH was adjusted to 7.0.

Phosphate uptake was tested using defined medium with $\mathrm{K}_{2} \mathrm{HPO}_{4}$ added as indicated. All solutions were prepared in double-distilled water.

The yeast was grown at $30^{\circ} \mathrm{C}$ on a rotary shaker and growth was measured turbidimetrically in a KlettSummerson colorimeter (Klett Manufacturing Co., New York, U.S.A.) at $540 \mathrm{~nm}$ (250 Klett units were equivalent to $0.2 \mathrm{mg}$ dry wt cells $\mathrm{ml}^{-1}$ ). The same procedure was used when measuring the antimycotic effect of amphotericin B on growth of cells from the early-exponential phase of growth ( $2 \mathrm{~h}$ ) or from the stationary phase $(24 \mathrm{~h})$, as well as on yeasts tested for the uptake of inorganic phosphate.

Potency of the polyene. The potency of amphotericin B was determined with C. albicans using $10^{4}$ to $10^{5}$ organisms $\mathrm{ml}^{-1}$ from a $24 \mathrm{~h}$ culture as inoculum. The preparation of amphotericin $\mathrm{B}$ used, fungizone (intravenous; E. R. Squibb \& Sons, New Brunswick, New Jersey, U.S.A.; 1.V. = $50 \mathrm{mg}$ ), had a minimum inhibitory concentration $\left(24 \mathrm{~h}\right.$ at $\left.30^{\circ} \mathrm{C}\right)$ of $\mathrm{I} \mu \mathrm{g} \mathrm{ml}^{-1}$.

Estimation of inorganic phosphate uptake. Phosphate was determined in the supernatant by the method of Ames (1966); the lower limit of sensitivity was $5 \mathrm{nmol}$ phosphate $\mathrm{ml}^{-1}$.

\section{RESULTS}

\section{Effect of age of yeast cells on the sensitivity to amphotericin $B$}

Gale et al. (I975) found that cells of $C$. albicans harvested during the early-exponential phase of growth were very sensitive to amphotericin B methyl ester and their sensitivity decreased as the culture passed into the stationary phase. In our experiments (Table 1 ) young cells (inoculum from a $2 \mathrm{~h}$ culture) were more sensitive to the antibiotic (at I $\mu \mathrm{g}$ $\mathrm{ml}^{-1}$ ) than cells from a $24 \mathrm{~h}$ culture. Even more strikingly, phosphate uptake in young cells was inhibited by amphotericin B more than in the old cells (Fig. 1), whereas there was almost no difference in the uptake between these two sets of cells in the absence of the antibiotic; about 15 to $20 \mathrm{nmol}$ phosphate $\mathrm{ml}^{-1}$ were taken up in $24 \mathrm{~h}$ in the absence of the antibiotic. The uptake of inorganic phosphate was very rapid, about $50 \%$ being taken up within $2 \mathrm{~min}$, though it slowed considerably afterwards. The uptake of phosphate ceased almost completely after contact of the yeast with the antibiotic for 4 to $5 \mathrm{~min}$.

\section{Effect of pre-incubating Candida cells with amphotericin $B$ on phosphate uptake}

Since even short ( 2 to $5 \mathrm{~min}$ ) contact of cells with amphotericin B inhibited their ability to take up phosphate we examined exposed cells to see if they retained the lesion upon removal of the antibiotic. Both young and old cells were treated with increasing concentrations of the antibiotic and incubated at $30^{\circ} \mathrm{C}$ for $\mathrm{I}$ or $2 \mathrm{~min}$. The cells were then centrifuged in the cold, taken up in saline to remove traces of the polyene; and resuspended in a drug-free medium to test for uptake of phosphate. Pre-incubating old cells with $0.25 \mu \mathrm{g}$ amphotericin B ml-1 for as little as 2 min inhibited the phosphate uptake by about $50 \%$, and a considerably stronger effect ( $85 \%$ inhibition) was seen in the young cells (Fig. 2). Cells exposed to the antibiotic at I or $2 \mu \mathrm{g} \mathrm{ml}^{-1}$ for I to 2 min were unable to take up any phosphate. Moreover, the polyene-treated cells leaked phosphate into the medium, greater leakage occurring in young cells. 
Table I. Effect of cell age on the sensitivity of growth and phosphate uptake to amphotericin $B$

Yeast extract medium $(20 \mathrm{ml})$ containing amphotericin B was held in Erlenmeyer flasks (100 $\mathrm{ml}$ ) and inoculated $\left(5 \times 10^{7}\right.$ cells $\left.\mathrm{ml}^{-1}\right)$ with $C$. albicans taken from cultures in the early-exponential phase of growth ( $2 \mathrm{~h}$ cells) or in the stationary phase ( $24 \mathrm{~h}$ cells). Subsequent growth was measured turbidimetrically. Phosphate uptake was measured after $2 \mathrm{~h}$; uptake by young cells in the absence of the polyene was taken to be $100 \%$.

Age of cells at time of inoculation

(h)

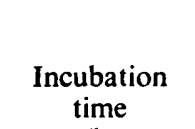

(h)

2

24

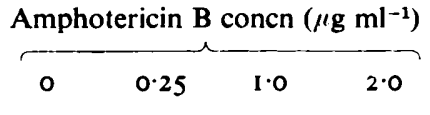

Growth (Klett units)

$\begin{array}{rr}55 & 55 \\ 113 & 83 \\ 245 & 103 \\ 380 & 173 \\ 720 & 320 \\ 103 & 107 \\ 107 & 107 \\ 135 & 170 \\ 320 & 260 \\ 640 & 600\end{array}$

Amphotericin B concn ( $\left.\mu \mathrm{g} \mathrm{ml}^{-1}\right)$

$\overbrace{0} 0.25 \quad 1.0 \quad 2.0$

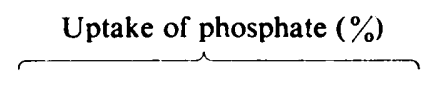

100 $28 \cdot 3 \quad 6 \cdot 6 \quad-45^{*}$

$91 \cdot 7 \quad 77 \cdot 5 \quad 26$

$9 \cdot 5$

- More phosphate was recovered than added; this increase was presumably due to release of cell-bound phosphate from the injured, polyene-treated cells.

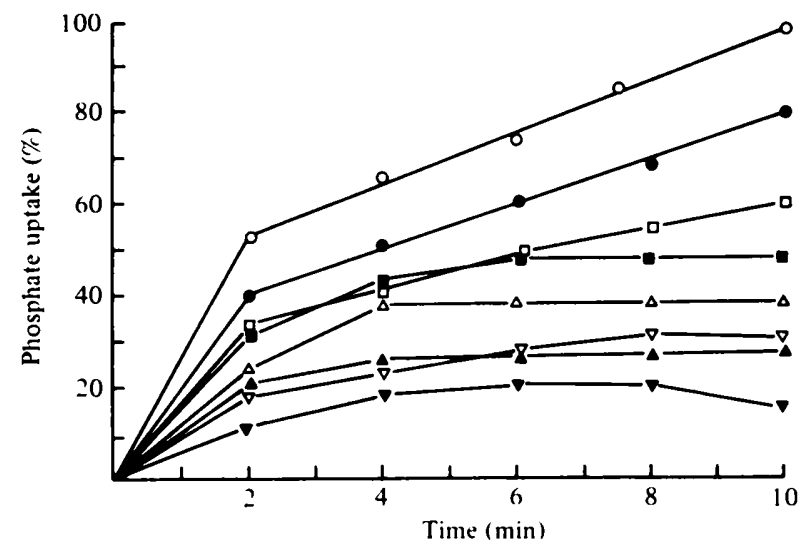

Fig. 1. Candida albicans $\left(0.02 \mathrm{mg}\right.$ dry $\left.\mathrm{wt} \mathrm{ml}^{-1}\right)$ from cultures in the early-exponential phase $(2 \mathrm{~h}$ growth, young cells) and in the stationary phase ( $24 \mathrm{~h}$ growth, old cells) was inoculated into $20 \mathrm{ml}$ defined medium containing $100 \mu \mathrm{M}-\mathrm{K}_{2} \mathrm{HPO}_{4}$ held in $100 \mathrm{ml}$ Erlenmeyer flasks. Amphotericin B was then added and the flasks were shaken at $30^{\circ} \mathrm{C}$. Samples were centrifuged and the supernatants were assayed for inorganic phosphate. Uptake of phosphate into young cells with amphotericin $\mathbf{B}$ at $\left(\mu \mathrm{g} \mathrm{ml}^{-1}\right): 0.25(\nabla) ; \mathrm{I} \cdot 0(\Delta)$; and $2.0(\nabla)$; and into old cells with amphotericin $\mathrm{B}$ at $\left(\mu \mathrm{g} \mathrm{ml}^{-1}\right)$ : $0.25(\sqcup) ; 1.0(\square)$; and $2.0(\triangle)$. Uptake of phosphate in the absence of amphotericin $B$ into young cells $(O)$ and old cells $(O)$. 


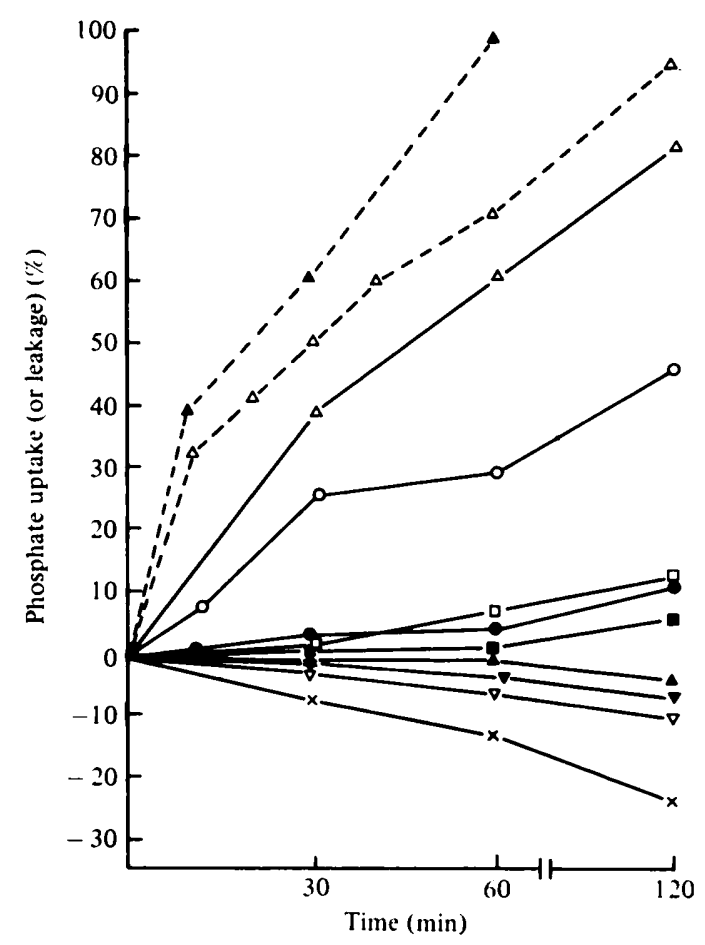

Fig. 2. Young and old cells (see legend to Fig. I) of $C$. albicuns were pre-incubated for $\mathrm{I}$ or $2 \mathrm{~min}$ at $30^{\circ} \mathrm{C}$ with amphotericin $\mathrm{B}$. The cells vere then rapidly removed by centrifuging in the cold, washed twice with saline and resuspended in the defined medium containing $20 \mu \mathrm{M}-\mathrm{K}_{2} \mathrm{HPO}_{\mathrm{P}}$. They were incubated at $30^{\circ} \mathrm{C}$ and sampled as indicated. Uptake of phosphate into young cells with 2 min exposure to amphotericin B at $\left(\mu \mathrm{g} \mathrm{ml}^{-1}\right): 0.25(\square) ; \mathrm{I} \cdot 0(\nabla)$; and $2.0(x)$; and into old cells with I min exposure to amphotericin B at $\left(\mu \mathrm{g} \mathrm{ml}^{-1}\right): 0.25(\triangle) ; \mathrm{I} \cdot 0(\bullet)$; and $2.0(\Delta)$; and with 2 min exposure at the same concentrations $(O, \mathbf{Q}, \nabla)$. Uptake of phosphate, without pre-incubation with amphotericin $B$, into young cells $(\triangle---\Delta)$ and old cells $(\triangle---\triangle)$.

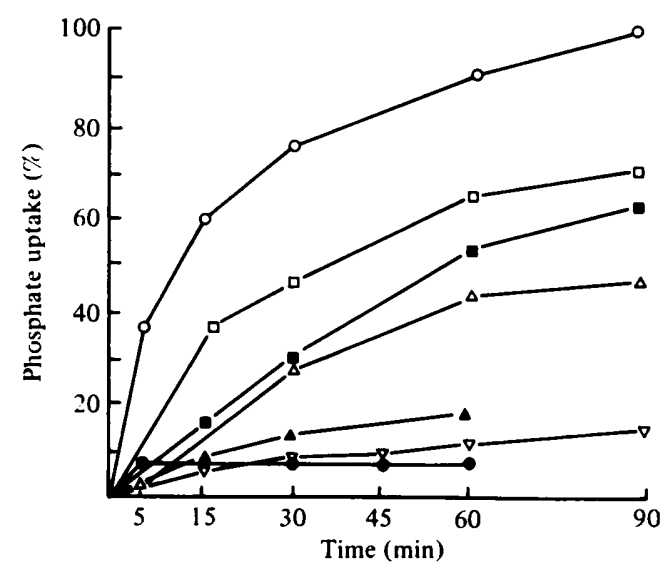

Fig. 3. Candida albicans $\left(0.02 \mathrm{mg}\right.$ dry $\left.\mathrm{wt} \mathrm{m}^{-1}\right)$ was starved for $30 \mathrm{~min}$ by incubating at $30^{\circ} \mathrm{C}$ in $0.85 \% \mathrm{NaCl}$. Defined medium (20 ml), glucose or vitamin solution (see Methods) was added and the yeast suspensions were assayed for phosphate uptake. Uptake of phosphate at $30^{\circ} \mathrm{C}$ into cells in saline alone $(\nabla)$; saline plus defined medium $(0)$; saline plus glucose at $0.1 \%(\Delta), 0.5 \%(\square)$ and $1.0 \%(\square)$; or saline plus vitamins $(\triangle)$. Uptake of phosphate at $8{ }^{\circ} \mathrm{C}$ into cells in saline plus defined medium $(\bullet)$. 


\section{Effect of medium components and of temperature on phosphate uptake by untreated C. albicans}

The rapid and sustained effect of amphotericin B on phosphate uptake by $C$. albicans indicated that the cell membrane was being affected; we therefore examined whether the uptake of phosphate by the yeast cells involved an active transport component.

No phosphate uptake could be seen in $C$. albicans at $8{ }^{\circ} \mathrm{C}$ in the defined medium, or at $30{ }^{\circ} \mathrm{C}$ in either saline or saline with vitamins. On the other hand, there was considerable uptake of phosphate by $C$. albicans at $30^{\circ} \mathrm{C}$ in the defined medium or even in saline with only glucose added (Fig. 3).

\section{DISCUSSION}

Alterations in the permeability of $C$. albicans and other eukaryotic cells induced by polyene antibiotics could come from interference with the synthesis of the cell membrane in an analogous manner to inhibition of the formation of cell wall components by penicillin in many bacterial species. Such a possibility seems rather unlikely because the polyenes exert their antibiotic effect, though to a lesser extent, even on non-growing cells. A more plausible mechanism is that these antifungal antibiotics bind specifically to the sterols of the eukaryotic cell membrane, and of yeast in particular, thereby interfering with the function of the latter as a permeability barrier (Demel, Van Deenen \& Kinsky, 1965; Lampen, I966; Hamilton-Miller, 1974; Kerridge \& Russell, 1975). Indeed the latter hypothesis, although still not fully proven, has gained wide support. Such an interpretation, however, does not exclude the possibility that additional sites and structures either separated from or linked with the cell membrane are affected by the polyenes. Thus, Stachiewicz \& Quastel (1963) have demonstrated that calcium ions protect $C$. albicans from the action of nystatin. We found that calcium ions protected cells against various polyene antibiotics; however, out of seven strains tested, the effect was limited to a single strain of the yeast Debaryomyces nicotianae. Since we could find no evidence for complex formation between the calcium ions and the antibiotic, we have assumed that the cation somehow attaches to the membrane sterol, i.e. the polyene-combining site, thereby preventing the drug from reaching it (Berdicevsky \& Grossowicz, 1972).

Recently, Gale et al. (1975) have shown that the sensitivity of C.albicans to amphotericin B methyl ester varied markedly with the phase of growth and depended on the formation of neutral lipids in the cell wall, a synthesis which augmented the non-specific binding of the drug. Thus, when the content of the neutral lipids increased, the sensitivity of the yeast to the antibiotic decreased. Gale et al. (1975) felt that the greater sensitivity of sphaeroplasts compared with intact cells towards amphotericin B methyl ester supported their hypothesis.

The experiments reported here exemplify the complexity of factors determining the sensitivity of the yeast cell to amphotericin. There was no uptake of phosphate, even in the absence of the antibiotic, by $C$. albicans without an energy supply (glucose) or at a low temperature (Fig. 3). Thus, the uptake of phosphate in the yeast appears to be achieved by an active transport mechanism (Goodman \& Rothstein, 1957; Rothstein \& Donovan, 1963; Knotkova \& Kotyk, 1972; Button, Dunker \& Morse, 1973) which requires an intact cell membrane.

The marked differences in the sensitivity towards amphotericin B of phosphate uptake in cells from young and old inocula (Fig. I, Table 1 ) point to the importance of a factor (or factors) synthesized by the yeast cell during growth, in addition to the membrane sterol. Thus, the hypothesis of Gale et al. (1975) could explain the considerable differences in the inhibition of phosphate uptake in cells of different 'age' by amphotericin B. Leakage of potassium ions is also an early sign of polyene-induced damage to the cell membrane (Lampen, 1966; Zygmunt, 1966; Gale, 1974). That the integrity of the cell membrane seems to be the more important factor is borne out by the high sensitivity of the uptake of 
phosphate (which is markedly affected after contact with the polyene for as little as $\mathbf{2}$ min) in contrast to the relative resistance of the cell as a whole. It is likely that yeasts differ in their capacity to take up the polyene (Gale et al., 1975). Thus, the delay occurring after cultures are treated with limiting concentrations of amphotericin (Table 1 ) could be due to growth of that fraction of cells which took up sub-inhibitory concentrations of the antibiotic. Another possibility is that the cultures are homogeneous with respect to polyene uptake and that the lag is an expression of the time required to repair the membrane lesion. At present, it is difficult to distinguish between these possibilities.

We thank Ms Nira Leider for her skilful technical assistance.j N. G. is an Established Investigator of the Chief Scientist's Bureau, Ministry of Health, Government of Israel.

\section{REFERENCES}

Ames, B. N. (1966). Assay of inorganic phosphate, total phosphate and phosphatases. Methods in Enzymology 8, 1 I 5-I 18.

BerdiceVsKY, I. \& Grossowicz, N. ( 1972). Reversal by calcium ions of the growth inhibition of Debaryomyces nicotianae caused by antifungal polyene antibiotics. Antimicrobial Agents and Chemotherapy 2, 1-7.

Button, D. K., Dunker, S. S. \& Morse, M. L. (1973). Continuous culture of Rhodotorila rubra: kinetics of phosphate--arsenate uptake, inhibition and phosphate-limited growth. Journal of Bacteriology $113,599-6 \mathrm{II}$.

Cirillo, V. P., Harsch, M. \& Lampen, J. $O$. (1964). Action of the polyene antibiotics filipin, nystatin and $N$-acetylcandidin on the yeast cell membrane. Journal of General Microbiology 35, 249-259.

Demel, R. A., Van Deenen, L. L. M. \& Kinsky, S. C. (1965). Penetration of lipid monolayers by polyene antibiotics. Correlation $\mathrm{with}$ selective toxicity and mode of action. Journal of Biological Chemistry 240, 2749-2753.

Gale, E. F. (1974). The release of potassium ions from Candida albicans in the presence of polyene antibiotics. Journal of General Microbiology 80, $45 I-465$.

Gale, E. F., Johnson, A. M., Kerridge, D. \& KoH, J. Y. (1975). Factors affecting the changes in amphotericin sensitivity of Candida albicans during growth. Journal of General Microbiology 87, 20-36.

Goodman, J. \& Rothstein, A. (1957). The active transport of phosphate into the yeast cell. Journal of General Physiology 40, 91 5-923.

Hamilton-Miller, J. M. T. (I974). Chemistry and biology of the polyene macrolide antibiotics. Bacteriological Reviews 37, 166-196.
Henis, Y. \& Grossowicz, N. (1960). Studies on the mode of action of antifungal heptaene antibiotics. Journal of General Microbiology 23, 345-355.

KerRidGe, D. \& Russell, N. J. (1975). Polyenes: actions and prospects. In Chemotherapy Progress, vol. 6, Proceedings of the Sixth International Congress of Chemotherapy, pp. I I I-I 16. New York and London: Plenum Publishing Corporation.

KINSKY, S. C. (1963). Comparative responses of mammalian erythrocytes and microbial protoplasts to polyene antibiotics and vitamin $A$. Archives of Biochemistry and Biophysics 102, $180-188$.

Knotkova, A. \& Kotyk, A. (1972). Role of sugars in phosphate transport in baker's yeast. Folia microbiologica $17,251-260$.

LAMPEN, J. O. (1966). Interference by polyenic antifungal antibiotics (especially nystatin and filipin) with specific membrane function. Symposia of the Society for General Microbiology 16, I I I-I 30.

Marini, F., Arnow, P. \& Lampen, J. O. (196I). The effect of monovalent cations on the inhibition of yeast metabolism by nystatin. Journal of General Microbiology 24, 5I-62.

Rothstein, A. \& Donovan, K. (1963). Interactions of arsenate with the phosphate-transporting system of yeast. Journal of General Physiology 46, 1075-1085.

Stachiewicz, E. \& Quastel, J. H. (1963). Amino acid transport in yeast and effects of nystatin. Canadian Journal of Biochemistry and Physiology 41, 397-407.

ZYGMUNT, W. A. (1966). Intracellular loss of potassium in Candida albicans after exposure to polyene antifungal antibiotics. Applied Microbiology r4, 953-956. 